\title{
The Impact of Macroeconomic Variables on Mutual Funds Performance in Ghana
}

\author{
Cai $\mathrm{Li}^{1}$, Rosemond Atampokah ${ }^{1}$, Helena Akolpoka ${ }^{2}$, Priscilla Avonie ${ }^{2}$, Baku R. Kwame ${ }^{3}$ \\ ${ }^{1}$ School of management, Jiangsu University, Zhenjiang, P.R. China \\ ${ }^{2}$ Business School, University of Ghana, Accra, Ghana \\ ${ }^{3}$ School of Finance and Economics, Jiangsu University, Zhenjiang, P.R. China \\ Corresponding author: gscaili@ujs.edu.cn
}

\begin{abstract}
Article Info

Volume 8 Issue 2

Page Number: 34-53

Publication Issue :

March-April-2021

\section{Article History}

Development across the globe has been an agenda many citizens of the world champion irrespective of the area, sector or discipline within which it is being advocated. Politically, socially, and in the world of economics, mutual fund has gained significance within country's economic environment. The phenomenal growth in the financial market of mutual funds can be attributed to the increase in the various financial schemes available, improvement in fund mobilization, as well as the growth of investments in the country. We examined the impact of macroeconomic variables on mutual fund performance of all mutual fund companies in Ghana over the period of 2008 to 2016. We performed correlation analysis, hence examined the co-movement of the returns from the selected funds with the key macroeconomic variables. We find macroeconomics variables positively affect the returns of funds. The effect comes by the amount of money available for investments. We further find exchange rate as the strongest macroeconomic variable affects the performance of mutual funds in Ghana. We established that Ghana receives a significant amount of foreign portfolio investment (FPI), where investors in other countries bring in their money to make investment on our financial markets. Our results provide evidence for fund managers on approach in dealing with macroeconomic conditions and its volatilities.
\end{abstract}

Accepted : 05 March 2021

Published : 15 March 2021
Keywords : Macroeconomics, mutual fund, performance, Inflation, Ghana Stock Exchange, Bank of Ghana.

\section{INTRODUCTION}

Development across the globe has been an agenda many citizens of the world champion irrespective of the area, sector or discipline within which it is being advocated. Politically, socially, and in the world of economics, development has been of much concern to the world. Developing the political and social sectors of a country is almost impossible with a dwindling economy, hence the need for a developed financial sector which strongly ensures economic growth. According to Fosu, Bondzie, \& Okyere (2014), most 
African countries became more interested in developing their capital market after the decline in aid from foreign sources decades ago. When investors invest in any financial assets such as a mutual fund in the capital markets, they invest their wealth in a venture for it to be managed by a fund manager with the primary objective of making returns on their investment over time. Kariuki (2014) agrees that the financial market has been significantly developed and the role played by mutual funds can never be underestimated in this regard.

In Ghana, the sector allows for investment of as low as $1 \$$ dollars, hence the interest of most Ghanaians regardless of their social status. Mutual funds in Ghana are in many types: the fixed income, money market, equity, balanced, index, and specialty funds among others. Investors of mutual funds in Ghana do not only have the advantage of having their funds managed by experts and the benefits of diversification, increased liquidity, convenience and rolling over earnings but also have the opportunity to invest as low as 1 dollar and also earn some returns. However, the performance of mutual funds is affected by macroeconomic indicators that affect the performance of financial assets in the capital market. The increasing knowledge about investment and the role that macroeconomic variables play in determining the performance of mutual funds has raised a lot of concerns among investors both current and prospective.

Notwithstanding the big argument, little research has been done on how macroeconomics factors affect mutual fund performance. The performance of mutual funds in the capital market is thus affected by these macroeconomic indicators to a very large extent. The study's motives stem from research into impact macroeconomic factors affect mutual fund performance (Fortin \& Michelson, 2005; Goetzman \& Ibbotson, 2009). The paper reaps the poor performance of the mutual funds and market indexes can be attributed to the measure of the level uncertainties and risk that is inherent within the economy. In Ghana, the statistics are poor, where the impact of macroeconomic variables on the economy of a country does not just affect a single or few individuals, it affects the economy of the entire country. Ghanaian setting is interesting for the following reasons. First, Ghana receives a significant amount of foreign portfolio investment (FPI) where investors in other countries bring in their money to make investment on our financial markets. As a result, we predict that macroeconomic variables affect the returns of funds of mutual fund investors in Ghana. Over the years, mutual fund in Ghana has gained significance within the country's economic environment. The phenomenal growth in the financial market of mutual funds can be attributed to the increase in the various financial schemes available, improvement in fund mobilization, as well as the growth of investments in the country. Therefore, we examined the impact of macroeconomic variables on mutual fund performance of mutual fund companies in Ghana for the period of 2008 to 2016. We find macroeconomic variables affect the returns of funds by affecting the amount of money available for investment. We further established macroeconomic variables affect the confidence of consumers who purchase shares in the mutual funds.

Our paper contributes to current literature in twofold. First, this study adds to the ongoing debate about how macroeconomic variables affect the mutual funds' performance of investors in Ghana. Second, even though limited number of studies have been carried out to assess macroeconomic variables impact in Ghana, but the few studies do not make significant number of them made available for scholars and policy makers as well as industry players to study and make decisions regarding the market. In addition, Ghana, which is widely regarded as Africa's fastestgrowing economy, may provide additional evidence for fund managers, and investors on how to properly 
manage funds, and examine the performance of their investments.

The rest of the paper is presented using the following structures. Section 2 reviews the related literature. Section 3 discusses the methodology. Section 4 introduces the data, reveals and discusses the empirical findings. Final section concludes the study.

\section{LITERATURE REVIEW}

Macroeconomic variables are important in an economy. In this section, four important macroeconomics variables: inflation, exchange rate, interest rate, and Gross Domestic Products (GDP) are considered.

\section{Inflation}

Inflation is measured by the persistent increase in the general prices of goods and services within an economy. Inflation which has both direct and indirect impact on the activities and various sectors within an economy is also reported to have a ripple effect on other economic variables such as exchange rates, unemployment, interest rate, investment and other variables (Asalou and Ogunmuyira, 2011). According to Frimpong and Oteng-Abayie (2011), there has been persistent increase in the prices of goods and services since 1983 following attempts for an economic recovery program. A study by Bakaert and Engstrom (2010) revealed that during periods of economic recession the uncertainties within the economy makes investors lose confidence in the economy. This is because during periods of the economic recession, the risk in the market tends to be high. This results in a higher risk premium which tends to reduce the value of the investor's equity with time. The economic recession tends to make investors highly risk averse making them reduce their equity contribution towards mutual funds until a point where their equity value will match the level of risk inherent in the economy.
Exchange Rate

Exchange rate can be defined as the price at which a country's currency can be bought or exchange for another country's currency (Olweny and Omondi, 2011). Investors who pool their funds into foreign investment packages in a foreign country are usually faced with the issue of currency risk. Currency risk can simply be described as the risk associated with changes in the value of a currency due to its responsiveness to the changes in the exchange rate (Adler and Dumas, 1984). Thus, exchange rate risk associated with currency risk is of major concern to investors who have foreign investment either in another country or a foreign investor in a domestic country. Some mutual funds are held in foreign countries other than in the domestic country (Ghana) and these are referred to as Pan African. For the purposes of stock valuation and measuring performance, there is a need to convert these Pan African Mutual Funds from their respective foreign currencies to the local or domestic currency which in this case is the Ghanaian Cedi. They are first converted into internationally recognized and widely accepted currencies that are used for international trading. These currencies include the US Dollar, the British Pound and the Euro for which the US Dollar is widely used. Even though exchange rate risk cannot be diversified completely, theorists believe that it can be managed through diversification in an efficient market. According to Ali, Rehman, Yilmaz, Khan and Afzal (2010), the arbitrage forces between an efficient foreign exchange system and the stock market consistently prices the risk for which investors are compensated through risk premiums.

\section{Interest Rate}

Interest rate can be defined as the cost of lending or borrowing money which is usually expressed as a percentage for a year. Mainga (2014) describes interest rate from the perspective of the 
borrower and the lender. He explains that to the borrower, interest rate is the cost of borrowing money or capital for a certain period of time and to the lender, it is the return or fee gained for lending money to a borrower for a stipulated and agreed period of time. Changes in economic events within an economy such as changes in government policies, economic recession, inflation and changes within the financial market (domestic and international) can have significant influence on the interest rates (Ugur \& Ozlen, 2012). For this reason, investors take great interest in the changes that occur with interest rates to make informed decisions on their investments and portfolios. Interest rate greatly influence the decision of investors as to how and which investment to allocate their resources. According to Syed and Anwar (2012), anytime interest rate changes investors tend to change the composition of their portfolios. They reduce their equity investment assets and invest more in fixed income earning assets when there is an increase in the interest rate. Interest rate has an equal impact on mutual funds which is a pool of different individual assets in a portfolio. The value of a mutual fund investment is determined by dividing the total market value of the fund (which includes dividends and interests less all incidental expenses) by the total number of shares outstanding to arrive at the Net Asset Value (NAV) of the fund. Since the NAV of the mutual fund is determined at market value, an increase in the interest rate can have serious repercussions on a bond fund. Similarly, if interest rate fall, the older bonds will be traded at a premium and NAV may be affected significantly (Boyte-White, 2015).

\section{Determinants of Mutual Fund Performance}

Investors as are most likely to invest in funds that have high performance. The performance or non-performance of a fund can however be attributed to some determinants which include the size of the fund, returns, turnover, age, loads, fees and expenses that are associated with that particular fund. Most funds are not able to outperform the market. However, it is reported that quite a few numbers of investors are able to make some good returns. Previous good performance of funds tends to influence the fund selection process and ability of investors as they seek for a better performance on their funds. Many authors have explored the relationship between fund size and the performance of mutual funds. Among them is Boudoukh and Richardson (2008) who identified that anytime the fund size is large, it is accompanied by high cost of fees which affects the performance of the fund.

However Gay (2008) and some other authors believe that investors with large fund sizes have the advantage of enjoying economies of scale. They believe that fund managers must have access to all necessary information and authority to be able to effectively and efficiently manage their funds without any managerial hindrances. This will ensure a better fund performance as it is in the case for funds managed by individuals. That is however not the case since fund managers are faced with the problem of hierarchical impediments that become hindrances for the processing of necessary information which affects the effective management and overall performance of the fund. Groenewold and Fraser (2010) identified another characteristic that affects the performance of funds to be the age of the fund. Examining funds away from on the US market and funds on the US market, he identified a relationship between fund age and fund performance. Fund age however for non-US funds was negatively correlated to fund performance but had an insignificant impact on funds on the US stock market. Mandelker (2008) identified some other factors that affect the performance of funds to the rate of money supply, the rate of inflation, interest rate, the growth of the Gross Domestic Product (GDP) and the 
exchange rate rather than just the fund size and age.

\section{Empirical Review}

There exist a number of literature on macroeconomic variables and its impact on mutual funds. All of these literatures include studies carried out to establish the correlation between macroeconomic variables and mutual funds. The studies were carried out in different parts of the world and with diverse methodlogy leading to varied results. Dash \& Kumar (2008) applied the Granger causality test in their quest to investigate the effect of macroeconomic variables on the returns and volatility of India's mutual fund sector. The study gathered data from the weekly returns and volatility of various macroeconomic variables over the periods of 2006-2008. The study found out that there was a significant impact from the growth of macroeconomic variables on most mutual funds though the returns and variance of returns of most of the mutual funds were unresponsive to the macroeconomic variables under study.

Kariuki (2014) also employed a casual research design in a study to make known how macroeconomic variables impact the financial performance of Kenya's mutual funds industry. Using the multiple linear regression model in analyzing the data collected, the study established that macroeconomic variables had an impact on mutual funds in Ghana in both negative and positive ways.

Njau (2013) in his study examined the impact of economic variables such as inflation, GDP growth rate, lending rates from banks and exchange rates on the performance of firms in Kenya. He measured the performance of the firms using return on investment as proxy and the selected macroeconomic variables because he believed they are very useful and greatly impact the performance of firms in Kenya. The data collected from 32 observations for the period of 2005-2012 was analyzed using a multiple regression model. It was revealed that the performance of private equity firms was greatly influenced by the selected macroeconomic variables with GDP, inflation and the lending rates of banks having the greatest influence on the performance of the private equity firms in Kenya.

In an analysis of the interaction between the prices mutual funds, exchange, and inflation rates within the Ghanaian economic sector, Ansong (n d) employed the vector autoregressive model on the stationary series of macroeconomic variables. The study made use of data covering the periods of 1997 to 2012. The Augmented Dickey Fuller (ADF) unit root test was used in analyzing the data collected. The finding made was that variables are in the same order of integration. In testing the long run relationship between mutual funds and the macroeconomic variables, Johansen co-integration was used and the finding was that variables were not co-integrated at $5 \%$ significance.

In a study by Miller and Show fang (2001), they examined how the decrease in the exchange rate affects performance on the stock market of South Korea and identified that anytime the exchange rates fall, it affects the returns on stock on the market. They also attributed the fluctuations in the stock market to the fluctuations that occur with the exchange rates. Bigdlou and Safari (2005) on the other hand examined how to reduce unsystematic risk in portfolios. They concluded that increasing the number of stocks in a portfolio can reduce the unsystematic risk. The varying of a portfolio's stocks can will greatly influence the performance of the portfolio based on the indicators of Sharp and Trainer.

Gay (2008) also decided studied how selected macroeconomic variables affect the returns on 
stock. He concluded in his study that in countries such as Brazil, Russia, India and China, exchange rate and the prices of oil had insignificant impact on the performance of stock market which is measured by the stock market index.

Tursoy, Gunsel and Rjoub (2008) in their study tested the Arbitrage Pricing Theory (APT) by employing the ordinary least square techniques on monthly data from February 2001 to September 2005 from the Istanbul Stock exchange in Turkey. The study used macroeconomic variables such as the supply of money, oil prices, consumer price index, exchange rate, interest rate, GDP, the foreign reserve, unemployment and a market pressure index which they created. Their conclusion from 11 industry portfolios showed no statistical significance between stock returns and the macroeconomic variables that were used in the study. They also added that the extent of impact of the macroeconomic variable on the stock or portfolio return largely depends on the characteristics that are peculiar to the industry.

Humpe and Macmillan (2007) also used the standard discounted value model to assess the relationship between some macroeconomic variables and Stock prices in US and Japan between the periods of 1965 to 2005. Using the co-integration analysis, they found a single cointegration vector between US and Japan stock prices and macroeconomic variables such as the industrial production, interest rate, exchange rate, consumer price index, the money supply and long-term interest rates. Using the data obtained from US, the researchers identified a positive relationship between the stock prices and industrial production. On the other hand, there was a negative relationship between the stock prices and both interest rate and the consumer price index. They added that there was a positive but statistically insignificant relationship between the supply of money and stock prices.
Using the data obtained from Japan, the researchers now identified two co-integrating vectors. They established a positive relationship between the prices of stocks and industrial production but a negative relationship between the stock prices and the supply of money. For the second co-integrating vector they also realized a negative relationship between the long-term interest rate and the consumer price index with the stock prices in the Japan. The researchers explained that the difference that existed between the results in both economies can be attributed to the sudden decline in the performance of the Japanese economy during the period of 1990 followed by the liquidity trap between the periods of 1990 and 2000 . Najarzadeh et al (2009) postulates that it is important to take into consideration the longterm equilibrium relationship between the stock price index of the Tehran Stock Exchange and real exchange rate and inflation rate. They identified that in the short term, stock prices are impacted positively from shocks in the real exchange rate and interest rate but a negatively impacted on in the long run.

In a study by Pourzamani et al (2010), they studied the impact of both managerial and environmental factors on the returns on mutual funds. They used 13 mutual funds in their analysis and identified a positive relationship between the fund return to volatility of the fund, fund age and the asset turnover rate. They also identified that there was a huge difference between the asset turnover rate, the fund expenses and the money growth rate with the fund return. Sajjadi et al (2010) in their study also used the co-integration test to examine the impact of some macroeconomic variables such as inflation, the growth in supply of money, the revenues from oil and the exchange rate on the stock cash return in the long term. They concluded from their analysis that there anytime the inflation rate increases, the growth rate of the 
cash return on the stock also increases. They added that there was a negative relationship between the revenues from the oil and the exchange rate with the growth rate of the cash returns on the stock.

Siqueira, De Carvalho and Gallucci (2011) researched into the impact of economic variables on the performance of private equity firms as well as venture capitalist funds in Brazil between the periods of 2007 to 2008. The findings of their research revealed a number of factors that are believed to affect the performance of investments. Among these factors are the size of the fund, the number of investments, whether or not there are co-investments, the experience of the fund manager, how close the manager is to the investment company and the board composition of the investment company.

Cheung and $\mathrm{Ng}$ (2011) also studied how changes in the macroeconomic variables reflect in the stock market indexes which are a measure of the stock performance. They narrowed their research to a few selected developed economies such as Canada, Germany, Italy, Japan and America. Their study showed that, anytime the changes in the stock market index can be attributed to the changes that occur with the individual macroeconomic variables. Bialkowski and Roger (2011) in their research also tested the performance and how durable mutual funds in Poland can be. The study was conducted with 140 sampled mutual funds within the years of 2000 - 2008 using a two-factor model of Carhart for the analysis. The findings from their research were that the performance of mutual funds will be negatively influenced if the legal institutions are weak and the capital markets are underdeveloped.

Mohammadreza and Esmaeel (2013) also examined the impact of both exchange and inflation rates on the return of mutual funds in
Iran. Using monthly data from 2008 to 2011, they tested the hypothesis of the study by investigating panel data for all the mutual funds within the stipulated years and used GIS procedure by Eviews7 software for the data analysis. The findings showed a significant positive relationship between the returns on the fund with exchange and inflation rate. They also added that the return on the fund can be significantly influenced by the assets and age of the fund.

Chen and Qin (2016) posited that the predictability of a fund cannot be attributed to the frequency of the return on the fund by rather the persistence in the fund performance. They arrived at this finding when they researched on the behavior of Investor Flows in Corporate Bond Mutual Funds analyzing a sample of corporate bonds from a period of 1991 - 2014 to prove that flows from the fund is influenced by the fund performance and macroeconomic conditions. Oehler, Pukthuanthong, Rummer and Thomas (2007) researched in to what determines the Private Equity Market in Europe. Using a data set that covered the period pf 1992 - 2003, the researchers adopted both fixed and random modelsfor the purpose of achieving the objectives of the study. The conclusions from the study revealed that the level of interest rate, the growth on the stock market, the rate of growth of the Gross Domestic Product (GDP) and Private Equity divestments have a positive and significant relationship with Private Equity. Elton and Gruber (1988) used the Arbitrage Pricing Theory (APT) to study the returns on equity in Japan. They used macroeconomic variables such as the money supply, industrial production and crude oil prices. Their findings from the study revealed that as the short-term interest rate rises, the stock or equity price also increases thus a positive relationship. 
A study by Adams and Tweneboah (2008) examined the role of macroeconomic variables on stock prices in Ghana. The study used the Johansen's multivariate co-integration test and innovation accounting techniques to analyze the data. The study measured stock price performance by using the Databank Stock Index and analyzed the Consumer Price Index, Treasury Bill Rate and the Exchange Rate as the macroeconomic variables. The conclusion from the study was that changes in the macroeconomic variables affect the stock index in Ghana.Lastly, Karimzadeh and Sultani (2010) also assessed the impact of macroeconomic variables on the index of stock prices for financial intermediators in the financial sector. They concluded from their findings that there was a positive impact of cash on the stock prices of financial intermediation industry. They added that even though there is a negative relationship between exchange rate and interest rate with the stock index, the impact of this relationship on the price of the stock is meaningless.

\section{Theoretical models}

We applied two theoretical models in our study. These models have direct relationship with the study.

The Capital Asset Pricing Model

The capital asset pricing model is a model that is used to price assets that are considered to have high risk associated with them. As developed Sharpe (2004), Lintner (1965) and Mossin (1966) it measures the risk and expected return on an asset. The model considers only one macroeconomic variable which is the return and risk on the market to the individual asset through the value of the beta $(\beta)$ which measures the systematic risk inherent in the market.
Arbitrage Pricing Theory

The Arbitrage Pricing Theory was propounded by Ross (1976) for the pricing of assets and further developed by Roll and Ross (1995). They explain that the returns on a portfolio is greatly influenced by the macroeconomic factors (that is GDP, inflation, interest rate, money supply) that are inherent in an economy as well as security specific influences such as the market indices, the investors' confidence and measures that are used to measure production levels. These macroeconomic factors such as inflation, GDP and interest rate can also be having their own form of systematic risk that influences the expected return on the asset or portfolio. For this reason, investors can assess whether securities have either been overpriced or underpriced. They are also able to assess the risk exposure on their portfolios in order to predict a gain or loss on an investment. Unlike the CAPM, the multi factor model (APT) also uses a linear relation of more than just one variable to predict the returns on an asset or portfolio. The theory has gained much significance and widely used to minimize to total risk in situations where macroeconomic variables are under consideration. According to Sinclair (1989) even though the APT model has gained much acceptance for the pricing of assets, it possesses to its users' methodological challenges, identification, choice and number of macroeconomic variables to be used for application in the absence of universally established factors. Qi and Maddala (2008) questioned the validity of the multifactor model when they realized that stock markets are not only unpredictable but most multifactor models are inefficient for the pricing of assets. Similarly, Beenstock and Chan (2007) developed a method that could be used test the Arbitrage Pricing Model (APT). They conducted their study with the macro variable model and identified the four macroeconomic variables for the British Security Market to be interest rates, the money supply, 
inflation and fuel and material costs. Groenewold and Fraser (2010) also examined the findings of Chen, Roll \& Ross (2004) on the APT model using the macroeconomic factors in Australia for the period of 1980-1994. They identified inflation, the interest rate and money supply were priced factors and consistently priced. However, they discovered less support for output, employment, exchange rates and balance of payments.

\section{Empirical Design}

We sampled all mutual fund companies in Ghana over the period of 2008-2016 from the security and exchange commission and Bank of Ghana. We exclude firms with missing information such as whether the investment company is registered, licensed and regulated by the Securities and Exchange Commission (SEC) and the Bank of Ghana (BOG), and if mutual fund must have been traded for a minimum of two or three years to have equity number to have equity value or number.

\section{Variable Measurement and Descriptions}

\section{Mutual Funds Performance Indicators}

ROI - Return on Investment

We proxy mutual fund performance, and Net Asset Value as Return on Investment. We measure return on investment as ending value of the fund minus beginning value of the fund all divided by the beginning value times $100 \%$. Specifically, Return on Investment = $\frac{\text { EndingValue }- \text { OpeningValue }}{\text { OpeningValue }} * 100$. However, we measure Net Asset Value as the market value of assets minus liabilities over the share of outstanding. Specifically, Net asset value = Markt value of Assets-Liabilities

$$
\text { Shares outstanding }
$$

\section{Macroeconomic Variables}

We used the interest rate, exchange rate, inflation, and GDP as the macroeconomic indicators for our study. For inflation as the persistent increase in the general price level within the country. We measure as the rate of increment of pricing over a period. Gross Domestic product is the monetary measure of goods and services. We then measure interest rate as amount charged on loans, and exchange rate as the value of the cedi in converting to another currency and money supply to GDP as the ratio of liquidity liabilities to GDP. We used natural log for the macro economic variables used in our study.

\section{Variables Description and Expected Correlation Coefficients}

\begin{tabular}{|l|l|l|l|}
\hline $\begin{array}{l}\text { Macroeconomic } \\
\text { variables }\end{array}$ & Definition & ROI & NAV \\
\hline $\begin{array}{l}\text { Gross Domestic } \\
\text { Product (GDP) }\end{array}$ & $\begin{array}{l}\text { Monetary } \\
\text { measure } \\
\text { of goods } \\
\text { and } \\
\text { services }\end{array}$ & + & + \\
\hline $\begin{array}{l}\text { Inflation Rate } \\
\text { (INF) }\end{array}$ & $\begin{array}{l}\text { The rate } \\
\text { of } \\
\text { increment } \\
\text { in pricing } \\
\text { over a } \\
\text { period }\end{array}$ & + & + \\
\hline $\begin{array}{l}\text { Interest } \\
\text { (INT) }\end{array}$ & $\begin{array}{l}\text { Amount } \\
\text { charged } \\
\text { on loans } \\
\text { taken }\end{array}$ & $+/-$ & $+/-$ \\
\hline $\begin{array}{l}\text { Exchange } \\
\text { (EXC) }\end{array}$ & $\begin{array}{l}\text { The value } \\
\text { of the cedi } \\
\text { in } \\
\text { converting }\end{array}$ & $+/-$ & $+/-$ \\
\hline
\end{tabular}




\begin{tabular}{|l|l|l|l|}
\hline & $\begin{array}{l}\text { to another } \\
\text { currency }\end{array}$ & & \\
\hline $\begin{array}{l}\text { Money supply to } \\
\text { GDP (M2GDP) }\end{array}$ & $\begin{array}{l}\text { The ratio } \\
\text { of } \\
\text { liquidity } \\
\text { liabilities } \\
\text { to GDP }\end{array}$ & $+/-$ & $+/-$ \\
\hline
\end{tabular}

\section{Data and Empirical Models}

We assess the impact of macroeconomic variables on the performance of mutual funds in Ghana. The sampled companies of the study include; Data Bank Financial Services, FirstBanc Financial Services, Gold Coast Fund Management and HFC Investment Services for the period of 2008 to 2016. However, we obtained data for interest rates, inflation, exchange rate and GDP on annual basis for 8 years period from Bank of Ghana. We performed correlation analysis, hence examined the co-movement of the returns from the selected funds with the key macroeconomic variables

\section{Empirical Results}

\section{Summary Statistics}

The summary statistics for all the variables used in our analysis is presented. Table 2 present six performance variables, six macroeconomic variable, and Ghana Stock Exchange (GSE) annual returns in percentage terms. The results show that, the Balanced Fund had an average ROI over the nine' year period of $22.56 \%$, a high standard deviation of 16.99 reflecting the volatility of the returns. There was a minimum value of $3 \%$ and a maximum value of $47 \%$. The average Net Asset Value (NAV) for the Balanced fund was 0.221 cedis for the nine' year period. However, the standard deviation for the NAV unlike the ROI was very low at 0.113 with a minimum value of 0.097 cedis and a maximum value of 0.402 .
Similarly, the Equity Fund investment fund recorded an average return over the period of $25.11 \%$ with a high standard deviation of 33.23945 reflecting the riskier nature of equities investments. The minimum return on the Equity Fund was $-10 \%$ while the maximum return on the Equity Fund was 84\% recorded in the year 2013 when the GSE had an annual return of 79\%. Equity Fund had the highest average NAV among the three funds of 1.51, a low standard deviation of 0.89 and a maximum value of 2.65. The Fund which is a money market fund had an average return over the period of $20.62 \%$, and a standard deviation of the 5.41 with a maximum value of 28.06 and a minimum of 12.18. Like the other mutual funds, the MFund had an average of 0.448 and a standard deviation of 0.228 . Over the nine-year period, the GSE had an annual return of $13.5 \%$ with a rather high standard deviation of 38.99. Ordinarily, finance theory has it that increased risk comes with increased returns, however, the mutual funds over the period had a higher return and a lower standard deviation, suggesting that their managers were ahead of the market. This speaks to the financial efficiency of the GSE, and suggests that the fund managers may have better information than the other market participants. The average interest rate measured by the 91-day treasury bill rate was $19.5 \%$, which was lower than the average returns for all three funds. Since this rate is the risk-free rate, it is said that investing in the funds was a financially sound decision to take. The interest rate however, had a low standard deviation of $4.94 \%$. The average rate of inflation during the period was $14.35 \%$, with the highest recorded annual inflation being $19.25 \%$. The average GDP growth rate for the entire period was $7.1 \%$, the highest GDP growth rate was $14.4 \%$ recorded in the year 2011 when Ghana had oil in commercial quantities. The lowest GDP growth rate was in the year 2016 which was an election year in Ghana. The average dollar exchange rate during the period was 2.19 cedis per dollar; the highest exchange 
rate recorded was 3.9 cedis per dollar while the lowest rate recorded was 1.05 cedis per dollar. The ratio of money supply to the GDP of the Ghanaian economy had an average value of $30.7 \%$, the standard deviation was 2.46 suggesting that generally the supply of money in the economy was not frequently changed and it reflects tight or rigid monetary policy. The results are as follows

Table 2. Summary of Variables

\begin{tabular}{lccccc}
\hline Variables & Obs & Mean & Std. Dev. & Min & Max \\
\hline \hline BFundROI & 16 & 22.5556 & 16.9861 & 3 & 47 \\
BFundNAV & 16 & 0.2207 & 0.1130 & 0.0971 & 0.4022 \\
EFundROI & 33 & 25.1111 & 33.2395 & -10 & 84 \\
EFundNAV & 33 & 11.5062 & 0.8910 & 0.5722 & 2.6501 \\
MFundROI & 32 & 20.6200 & 5.4102 & 12.1800 & 28.0600 \\
MFundNAV & 32 & 0.4468 & 0.2277 & 0.2067 & 0.8700 \\
GSEReturn & 36 & 0.1350 & 0.3899 & -0.4680 & 0.7880 \\
INT & 36 & 0.1955 & 0.0494 & 0.1069 & 0.2590 \\
INF & 36 & 0.1436 & 0.0372 & 0.0873 & 0.1925 \\
GDPG & 36 & 7.1567 & 3.5423 & 3.6000 & 14.4000 \\
EXCH & 36 & 2.1929 & 1.0545 & 1.0524 & 3.9098 \\
M2GDP & 36 & 0.3075 & 0.0246 & 0.2746 & 0.3420 \\
\hline \hline
\end{tabular}

Note: BFund represents Balanced Fund, EFund means Equity Fund, MFund represents Money Market Fund, ROI means return on investment, NAV is net asset value, inf represents inflation rate and gdpg represents gross domestic product growth, INT stands for interest rate, M2GDP means money supply to GDP, EXCH is exchange rate

\section{Correlation Among Variables}

We present the correlation matrix for all the variables used in the study. Our study mentioned few pair wise correlations that are worth, first, the correlation between NAV of the Balanced Fund and the exchange rate which recorded a correlation coefficient of 0.974 and a correlation with the money supply ratio of 0.9114 . we observed that the NAV of the mutual funds showed a stronger correlation with the macroeconomic indicators than the ROI of the funds did. This could mean that the NAV is more affected by the macroeconomic indicators than the ROI which is simply a return calculation. The NAV reflects the growth in assets of the fund which is perhaps more closely related to the macro economy as opposed to the ROI. 
Table 3 Correlation Matrix for Variables

\begin{tabular}{|c|c|c|c|c|c|c|c|c|c|c|c|c|}
\hline & $\begin{array}{c}\text { BFundR } \\
\text { OI }\end{array}$ & $\begin{array}{c}\text { BFundN } \\
\text { AV }\end{array}$ & $\begin{array}{c}\text { EFundR } \\
\text { OI }\end{array}$ & $\begin{array}{c}\text { EFundN } \\
\text { AV }\end{array}$ & $\begin{array}{l}\text { MFundR } \\
\text { OI }\end{array}$ & $\begin{array}{c}\text { MFundN } \\
\text { AV }\end{array}$ & $\begin{array}{c}\text { GSERet } \\
\text { urn }\end{array}$ & INT & INF & $\begin{array}{c}\text { GDP } \\
\text { G }\end{array}$ & $\begin{array}{c}\text { EXC } \\
\mathrm{H}\end{array}$ & $\begin{array}{c}\text { M2G } \\
\text { DP }\end{array}$ \\
\hline \multicolumn{13}{|l|}{ BFundR } \\
\hline OI & 1 & & & & & & & & & & & \\
\hline \multicolumn{13}{|l|}{ BFundN } \\
\hline $\mathrm{AV}$ & -0.175 & 1 & & & & & & & & & & \\
\hline \multicolumn{13}{|l|}{ EFundR } \\
\hline OI & 0.4362 & 0.3955 & 1 & & & & & & & & & \\
\hline \multicolumn{13}{|l|}{ EFundN } \\
\hline AV & -0.1267 & 0.9621 & 0.5226 & 1 & & & & & & & & \\
\hline \multicolumn{13}{|l|}{ MFundR } \\
\hline OI & -0.1868 & 0.4226 & 0.0576 & 0.4827 & 1 & & & & & & & \\
\hline \multicolumn{13}{|l|}{ MFundN } \\
\hline $\mathrm{AV}$ & -0.237 & 0.9873 & 0.2689 & 0.9128 & 0.3871 & 1 & & & & & & \\
\hline \multicolumn{13}{|l|}{ GSERetu } \\
\hline $\mathrm{rn}$ & 0.9128 & -0.1776 & 0.4663 & -0.01251 & -0.3894 & -0.249 & 1 & & & & & \\
\hline INT & -0.2665 & 0.4281 & 0.065 & 0.4901 & 0.8945 & 0.3975 & -0.4241 & $\begin{array}{c}1 \\
0.85\end{array}$ & & & & \\
\hline INF & -0.0881 & 0.3135 & -0.1275 & 0.3294 & 0.8584 & 0.3103 & -0.3641 & $\begin{array}{c}44 \\
0.89\end{array}$ & $\begin{array}{c}1 \\
0.79\end{array}$ & & & \\
\hline GDPG & 0.1021 & -0.6193 & -0.1911 & -0.6476 & -0.8914 & -0.5995 & 0.3315 & $\begin{array}{c}24 \\
0.50\end{array}$ & $\begin{array}{c}78 \\
0.39\end{array}$ & $\begin{array}{c}1 \\
0.66\end{array}$ & & \\
\hline EXCH & -0.3178 & 0.9744 & 0.2684 & 0.9258 & 0.4538 & 0.9818 & -0.3579 & $\begin{array}{c}37 \\
0.31\end{array}$ & $\begin{array}{c}19 \\
0.14\end{array}$ & $\begin{array}{c}86 \\
0.48\end{array}$ & $\begin{array}{c}1 \\
0.94\end{array}$ & \\
\hline M2GDP & -0.4366 & 0.9114 & 0.2259 & 0.8769 & 0.2645 & 0.9257 & -0.41 & 18 & 59 & 84 & 54 & 1 \\
\hline
\end{tabular}

Note: BFund represents Balanced Fund, EFund means Equity Fund, MFund represents Money Market Fund, ROI means return on investment, NAV is net asset value, inf represents inflation rate and gdpg represents gross domestic product growth, INT stands for interest rate, M2GDP means money supply to GDP, EXCH is exchange rate.

Table 4. Correlation Between Annual Returns of Balanced Fund and other Variables

\begin{tabular}{lccc}
\hline & $\begin{array}{c}\text { Annual Return } \\
\text { rho }\end{array}$ & $\mathrm{p}$ & count \\
\hline \hline GSEReturn & 0.7601 & 0.0175 & 36 \\
INT & -0.2692 & 0.4837 & 36 \\
INF & -0.0949 & 0.8080 & 36 \\
GDPG & 0.0995 & 0.7989 & 36 \\
EXCH & -0.3079 & 0.4203 & 36 \\
M2GDP & -0.4244 & 0.2549 & 36 \\
\hline \hline
\end{tabular}

BFund represents Balanced Fund, GSEReturn means all index returns, inf represents inflation rate and gdpg represents gross domestic product growth, INT stands for interest rate, M2GDP means money supply to GDP, EXCH is exchange rate respectively 
Table (4) presents the correlation coefficients between returns on the Ghana Stock Exchange, and the macroeconomic variables. The table shows that the Balanced Fund has a positive correlation with the Ghana stock exchange (GSE) with a coefficient of 0.7601 which is strong. The Balanced Fund had a negative correlation coefficient with interest rates and with inflation; however, the GDP growth rate recorded a weakly positive correlation with the returns of the Balanced Fund using the ROI as our benchmark. The United States Dollar exchange rate with cedi had a negative correlation with the performance of the Balanced Fund suggesting that a depreciating cedi is generally bad for the performance of the fund. The ratio of money supply in the economy to the gross domestic product also had negative correlation with the returns on the Balanced Fund suggesting that an increase in the supply of money in the economy is generally bad for the performance of the fund.

Table 5. MFund Correlation with Macroeconomic Variables

\begin{tabular}{lccc}
\hline & $\begin{array}{c}\text { Annual Return } \\
\text { rho }\end{array}$ & $\mathrm{P}$ & Count \\
\hline \hline GSEReturn & -0.3888 & 0.3010 & 36 \\
INT & 0.8791 & 0.0018 & 36 \\
INF & 0.8584 & 0.0031 & 36 \\
GDPG & -0.8912 & 0.0013 & 36 \\
EXCH & 0.4538 & 0.2199 & 36 \\
M2GDP & 0.2645 & 0.4915 & 36 \\
\hline \hline
\end{tabular}

Note: BFund represents Balanced Fund, GSEReturn means all index returns, inf represents inflation rate and gdpg represents gross domestic product growth, INT stands for interest rate, M2GDP means money supply to GDP, EXCH is exchange rate

The MFund, which is a money market fund and thus has no investments on the Ghana Stock Exchange, had a negative correlation with the returns of the MFund. Unsurprisingly however, the returns of the MFund had a positive correlation with the interest rates, the relationship was also very strong with a correlation coefficient of 0.8791 which is close to one. Inflation is also positively correlated to the ROI of the MFund as expected due to the impact that inflation has on the interest rates; high inflation rates correspond to higher interest rates to compensate for the delayed consumption. The economic growth rate (GDPG) recorded a strongly negative correlation with the performance of the MFund. Historically, by examining the data, we observed that in years where GDP growth increased, interest rates and inflation were lower, however, low growth years were more synonymous with higher levels of inflation and interest rates. The USD exchange rate with cedi was positively related to the returns on the MFund, as was the level of money supply in the economy. 
Table 6. Equity Fund Correlations with Macroeconomic Variables

\begin{tabular}{lccc}
\hline & $\begin{array}{c}\text { Annual Return } \\
\text { rho }\end{array}$ & $\mathrm{P}$ & Count \\
\hline \hline GSEReturn & 0.4660 & 0.2061 & 36 \\
INT & 0.0650 & 0.8681 & 36 \\
INF & -0.1275 & 0.7437 & 36 \\
GDPG & -0.1911 & 0.6224 & 36 \\
EXCH & 0.2684 & 0.4850 & 36 \\
M2GDP & 0.2259 & 0.5589 & 36 \\
\hline \hline
\end{tabular}

Note: BFund represents Balanced Fund, GSEReturn means all index returns, inf represents inflation rate and gdpg represents gross domestic product growth, INT stands for interest rate, M2GDP means money supply to GDP, EXCH is exchange rate

The Equity Fund investment fund is an equities only mutual fund with about seventy percent of assets invested on the GSE and the other thirty percent invested in equities across the African continent. The fund recorded a positive correlation with the Ghana Stock Exchange although it was not a very strong correlation $(<0.5)$. Interest rates were positively and weakly correlated to the ROI of the EFund investment fund. Interest rates were negatively correlated to the ROI of the EFund investment fund; this correlation was rather weak with a coefficient of 0.0649. The ROI of EFund had a negative correlation with the level of inflation however the correlation coefficient of -0.1275 was rather weak. Likewise, the ROI of EFund had a negative correlation coefficient with the economic growth rate, the reported coefficient of -0.1910 suggests that the relation is weak. Both the dollar exchange rate and the money supply variable had positive correlation coefficients with the ROI of EFund, the correlation coefficients were rather low and thus they suggest that the correlation between these variables is weak.

Table 6. Balanced Fund NAV Correlation with Macroeconomic Variables

\begin{tabular}{lccc} 
& NAV & & \\
& rho & $\mathrm{P}$ & Count \\
\hline \hline GSEReturn & -0.1580 & 0.6847 & 36 \\
INT & 0.4281 & 0.2503 & 36 \\
INF & 0.3135 & 0.4114 & 36 \\
GDPG & -0.6193 & 0.0753 & 36 \\
EXCH & 0.9744 & 0.0008 & 36 \\
M2GDP & 0.9114 & 0.0006 & 36 \\
\hline \hline
\end{tabular}

Note: BFund represents Balanced Fund, GSEReturn means all index returns, inf represents inflation rate and gdpg represents gross domestic product growth, INT stands for interest rate, M2GDP means money supply to GDP, EXCH is exchange rate respectively. 
The correlation between the net asset value (NAV) of all three funds, and the macroeconomic variables and the returns on the GSE were estimated. The NAV of the BFund which has more than seventy percent of its assets invested in equity with the remaining thirty percent invested in debt, had a negative and weak correlation with the returns on the GSE all-share index. However, the correlation coefficient between the NAV of the BFund over the nine' period used in our analysis, and the level of interest rates was positive with a value of 0.4281 . The correlation coefficient between the NAV and the inflation rate was also positive but was marginally weaker than the coefficient recorded for the level of interest rates. The correlation coefficient between the NAV of the BFund and the GDP growth rate was negative and rather high at 0.6193. Finally, the NAV of the BFund recorded strong and positive correlation coefficients with both the dollar exchange rate and the money supply within the economy.

Table 7. MFund NAV Correlation with Macroeconomic Variables

\begin{tabular}{lccc} 
& $\begin{array}{c}\text { NAV } \\
\text { rho }\end{array}$ & $\mathrm{p}$ & count \\
\hline \hline GSEReturn & -0.2500 & 0.5165 & 36 \\
INT & 0.4023 & 0.2831 & 36 \\
INF & 0.3103 & 0.4164 & 36 \\
GDPG & -0.5996 & 0.0879 & 36 \\
EXCH & 0.9818 & 0.0002 & 36 \\
M2GDP & 0.9257 & 0.0003 & 36 \\
\hline \hline
\end{tabular}

Note: BFund represents Balanced Fund, GSEReturn means all index returns, inf represents inflation rate and gdpg represents gross domestic product growth, INT stands for interest rate, M2GDP means money supply to GDP, EXCH is exchange rate respectively.

From the results, net asset value (NAV) of a mutual fund, represents the price at which shares in the mutual fund can be redeemed or bought, it is the value of each share of the mutual fund. For the MFund, which is a purely money market fund, the correlation between the NAV and the returns on the GSE was negative which is expected. Besides, the NAV of the MFund was positively related to the interest rate suggesting that whenever interest rates rise, the value of each share of the fund also rose. Likewise, the NAV of the MFund was positively correlated with the level of inflation with a coefficient of 0.3103 . The correlation coefficient recorded for the NAV of the MFund and the GDP growth rate, was -0.5995 which is negative. This result was unexpected. For the dollar exchange rate and the money supply in the economy, the correlation coefficients recorded were both positive and very strong. 
Table 8. Equity Fund NAV Correlation with Macroeconomic Variables

\begin{tabular}{|c|c|c|c|}
\hline & $\begin{array}{c}\text { NAV } \\
\text { rho }\end{array}$ & $\mathrm{p}$ & count \\
\hline GSEReturn & -0.1232 & 0.5165 & 36 \\
\hline INT & -0.7935 & 0.7521 & 36 \\
\hline INF & 0.3294 & 0.0107 & 36 \\
\hline GDPG & -0.6476 & 0.0593 & 36 \\
\hline $\mathrm{EXCH}$ & 0.9258 & 0.0003 & 36 \\
\hline M2GDP & 0.8769 & 0.0019 & 36 \\
\hline
\end{tabular}

Note: BFund represents Balanced Fund, GSEReturn means all index returns, inf represents inflation rate and gdpg represents gross domestic product growth, INT stands for interest rate, M2GDP means money supply to GDP, EXCH is exchange rate respectively

Table 8 presents the correlation coefficient recorded for the NAV of the EFund investment fund and the macroeconomic variables as well as the returns on the Ghana Stock Exchange (GSE). From the results, the NAV of EFund and the returns on the Ghana Stock Exchange were weakly, and negatively correlated with a correlation coefficient of -0.1232 suggesting that when the GSE increases in value, the NAV of EFund decreases in value. However, the level of interest rates was negatively correlated to the NAV of EFund while inflation showed a positive correlation with the NAV of EFund. Following the trend of the NAV of the two other funds being analyzed, the NAV of EFund recorded a high and negative correlation with the GDP growth rate. The correlation coefficients between the NAV of EFund and the dollar exchange rate as well as the money supply, were both strongly positive suggesting that when the NAV of EFund increases both the dollar exchange rates and the money supply in the economy also increased.

\section{Conclusions and Policy Recommendations}

We examined the impact of macroeconomic variables on mutual fund performance of all mutual fund companies over the period of 2008 to 2016 in Ghana. We used companies with accurate information from sampled companies and Bank of Ghana. To do this, we specifically estimated the two performance ratios for the mutual funds for the period beginning from the year 2008 to the year 2016. We performed correlation analysis, hence examined the comovement of the returns from the selected funds with the key macroeconomic variables.

We find macroeconomics variables positively affect the returns of funds. The effect comes by the amount of money available for investments. Hence, macroeconomic variables affect the confidence of consumers who purchase shares in the mutual funds. We further established that, the exchange rate is the strongest macroeconomic variable that affects the performance of mutual funds in Ghana. We established that Ghana receives a significant amount of foreign portfolio investment (FPI), where investors 
in other countries bring in their money to make investment on our financial markets. Overall, our results find that, when the exchange rate is low, the returns earned on these investments are higher in real terms, than when exchange rates are high. Hence, we the results explains the negative correlation between the exchange rate and the fund performance. Our results add to the literature by providing further evidence that fund managers with mutual fund firms must reconsider their approach in dealing with macroeconomic conditions and its volatilities. It is evidenced by our results, that there are some macroeconomic factors that have influence on the investment of mutual funds. Our results did not include the returns on the Ghana Stock Exchange. This would have enabled the study to investigate how these variables moved together over the period. We call for future studies in addressing this issue by examining the relationship between returns on the Ghana Stock Exchange and mutual fund performance.

\section{REFERENCES}

[1]. Adam, A., \& Tweneboah, G. (2008). Macroeconomic factors and stock market movement: Evidence from Ghana.

[2]. Adler, M., \& Dumas, B. (1984). Exposure to currency risk: definition and measurement. Financial management, 41-50.

[3]. Alam, M., \& Uddin, G. (2009). Relationship between interest rate and stock price: empirical evidence from developed and developing countries.

[4]. Ali, I., Rehman, K. U., Yilmaz, A. K., Khan, M. A., \& Afzal, H. (2010). Causal relationship between macro-economic indicators and stock exchange prices in Pakistan. African Journal of Business Management, 4(3), 312-319.

[5]. Amunga, P. I. (2015). Factors Affecting Performance of Mutual Funds in Kenya (Doctoral dissertation, University of Nairobi).
[6]. Bekaert, G., \&Engstrom, E. (2010). Inflation and the stock market: Understanding the "Fed Model". Journal of Monetary Economics, 57(3), 278-294.

[7]. Beenstock, M., \& Chan, K. F. (1986). Testing the arbitrage pricing theory in the United Kingdom. Oxford Bulletin of Economics and Statistics, 48(2), 121-141.

[8]. Białkowski, J., \&Otten, R. (2011). Emerging market mutual fund performance: Evidence for Poland. The north american Journal of economics and finance, 22(2), 118-130.

[9]. Bodie, Z., Kane, A., \& Marcus, A. (2010). Investments, 9th ed.

[10]. Boudoukh, J., Richardson, M., Subrahmanyam, M., \& Whitelaw, R. F. (2002). Stale prices and strategies for trading mutual funds. Financial Analysts Journal, 58(4), 53-71.

[11]. Brinson, G. P., Singer, B. D., \&Beebower, G. L. (1991). Determinants of portfolio performance II: An update. Financial Analysts Journal, 47(3), 40-48.

[12]. Chen, N. F., Roll, R., \& Ross, S. A. (1986). Economic forces and the stock market. Journal of business, 383-403.

[13]. Chen, Y., \& Qin, N. (2016). The behavior of investor flows in corporate bond mutual funds. Management Science, 63(5), 13651381.

[14]. Cheung, Y. W., \& Ng, L. K. (1998). International evidence on the stock market and aggregate economic activity. Journal of empirical finance, 5(3), 281-296.

[15]. Chevalier, J., \& Ellison, G. (1997). Risk taking by mutual funds as a response to incentives. Journal of Political Economy, 105(6), 11671200

[16]. Dash, M. (2008). A study on the effect of macroeconomic variables on Indian Mutual Funds. 
[17]. Dudwick, N., Kuehnast, K., Jones, V. N., \&Woolcock, M. (2006). Analyzing social capital in context. A guide to using qualitative methods and data.

[18]. Elton, E. J., \& Gruber, M. J. (1988). A multiindex risk model of the Japanese stock market. Japan and the World Economy, 1(1), 21-44.

[19]. Fama, E. F., \&MacBeth, J. D. (1973). Risk, return, and equilibrium: Empirical tests. Journal of political economy, 81(3), 607-636.

[20]. Fortin, R., \& Michelson, S. (2005). Active international mutual fund management; can managers neat the index? Managerial Finance, 31(1), 41-51.

[21]. Bondzie, E. A., Fosu, G. O., \&AsareOkyere, G. (2014). Does Foreign Direct Investment really affect Ghana's Economic Growth?.

[22]. Frimpong, J. M., \&Oteng-Abayie, E. F. (2010). When is inflation harmful? Estimating the threshold effect for Ghana. American Journal of Economics and Business Administration, 2(3), 232.

[23]. Gay, R. D. (2016). Effect of macroeconomic variables on stock market returns for four emerging economies: Brazil, Russia, India, and China. The International Business \& Economics Research Journal (Online), 15(3), 119.

[24]. Goetzmann, W. N., \& Ibbotson, R. G. (2006). The equity risk premium: essays and explorations. Oxford University Press.

[25]. Groenewold Fraser, N. P. (1997). Share prices and macroeconomic factors. Journal of Business Finance \& Accounting, 24(9-10), 1367-1383.

[26]. Humpe, A., \& Macmillan, P. (2009). Can macroeconomic variables explain long-term stock market movements? A comparison of the US and Japan. Applied Financial Economics, 19(2), 111-119.
[27]. ICI, (2008) Mutual Fund Fact Book, Washington, D.C.: Investment Company Institute.

[28]. Miller, K. D., Jeffrey, F. J., \&Mandelker, G. (1976). The "Fisher effect" for risky assets: An empirical investigation. The Journal of finance, 31(2), 447-458.

[29]. Jawaid, S. T., \&UlHaq, A. (2012). Effects of interest rate, exchange rate and their volatilities on stock prices: evidence from banking industry of Pakistan. Theoretical \& Applied Economics, 19(8).

[30]. Jensen, M. C. (1968). The performance of mutual funds in the period 1945-1964. The Journal of finance, 23(2), 389-416.

[31]. Kaneza, C. (2016). Factors Affecting the Financial Performance of Commercial Banks Listed on the Nairobi Securities Exchange (Doctoral dissertation, United States International University-Africa).

[32]. Kariuki, E. C. (2014). Effect of Macroeconomic Variables on Financial Performance of Mutual Funds Industry in Kenya. school of business, university of nairobi.

[33]. KUNG'U, N. D. (2013). The effect of selected macroeconomic variables on the financial performance of private equity firms in Kenya. Unpublished MBA Project, University of Nairobi.

[34]. Lemantile, A. L. (2017). Effects of MacroEconomic Factors on the Financial Performance of Mutual Funds in Kenya (Doctoral dissertation, United States International University- Africa).

[35]. Lintner, J. (1975). The valuation of risk assets and the selection of risky investments in stock portfolios and capital budgets. In Stochastic Optimization Models in Finance (pp. 131155).

[36]. Lu, G. M., Metin IV, K., \&Argac, R. (2001). Is there a long run relationship between stock 
returns and monetary variables: evidence from an emerging market. Applied financial economics, 11(6), 641-649.

[37]. Mainga, S. (2014). Effect of Macro-Economic Factors on Stock Returns at the Nairobi Stock Exchange (Doctoral dissertation, United States International University-Africa).

[38]. Marfo, K. N. (2017). The performance of mutual fund in Ghana: a case study of Anidaso Mutual Fund (Doctoral dissertation).

[39]. Markowitz, H. (1952). Portfolio selection. The journal of finance, 7(1), 77-91.

[40]. Monjazeb, M., \&Ramazanpour, E. (2013). The Effect of Economic Factors on The Efficiency of Mutual Funds in Iran SeyedehJavaneh Ahmadi Tulamy. Technical Journal of Engineering and Applied Sciences, 3(15), 1707-1711.

[41]. Mossin, J. (1966). Equilibrium in a capital asset market. Econometrica: Journal of the econometric society, 768-783.

[42]. Oehler, A., Pukthuanthong, K., Rummer, M., \& Walker, T. (2007). Venture capital in Europe: closing the gap to the US. In Venture capital in Europe (pp. 3-17).

[43]. Olweny, T., \&Omondi, K. (2011). The effect of macro-economic factors on stock return volatility in the Nairobi stock exchange, Kenya. Economics and Finance review, 1(10), 34-48.

[44]. Özlen, S., \& Ergun, U. (2012). Macroeconomic factors and stock returns. International Journal of Academic Research in Business and Social Sciences, 2(9), 315.

[45]. Qi, M., \&Maddala, G. S. (1999). Economic factors and the stock market: a new perspective. Journal of Forecasting, 18(3), 151166.

[46]. Ramey, G., \& Ramey, V. A. (1994). Crosscountry evidence on the link between volatility and growth (No. w4959). National bureau of economic research.
[47]. Reilly, F. K., \& Brown, K. C. (2011). Investment analysis and portfolio management. Cengage Learning.

[48]. Ross, S. A. (1976). The arbitrage theory of capital asset pricing, 'Journal of Economic Theory'.

[49]. Sajjadi H., Azar A., Farazmand H., Ali Sofieh H. (2010) Examining the relationship between macroeconomic variables and Tehran securities stock exchange price index. Accounting Studies, No.6.

[50]. Samadi, S., Bayani, O., \&Ghalandari, M. (2012). The relationship between macroeconomic variables and stock returns in the Tehran stock exchange. International Journal of Academic Research in Business and Social Sciences, 2(6), 559.

[51]. Saunders, M., \& Lewis, P. (2016). In Thornhill Adrian. Research methods for business students, 7.

[52]. Sharpe, W. F. (1964). Capital asset prices: A theory of market equilibrium under conditions of risk. The journal of finance, 19(3), 425-442.

[53]. Sharpe, W. F. (1966). Mutual fund performance. The Journal of business, 39(1), 119-138.

[54]. Sinclair, N. A. (1984). Aspects of the factor structure implicit in the Australian industrial equity market: February 1958 to August 1977. Australian Journal of Management, 9(1), 2336.

[55]. Singh, T., Mehta, S., \&Varsha, M. S. (2011). Macroeconomic factors and stock returns: Evidence from Taiwan. Journal of economics and international finance, 3(4), 217-227.

[56]. Siqueira, E. M. R., de Carvalho, A. G., \&Netto, H. G. (2011). Determinants of Success in Private Equity-Venture Capital Investments. Brazilian Review of Finance, 9(2), 189-208.

[57]. Smirlock, M., \&Yawitz, J. (1985). Asset returns, discount rate changes, and market 
efficiency. The Journal of Finance, 40(4), 1141-1158.

[58]. Tieku, E. (2016). An examination of the effect of macroeconomic variables on Ghana stock market returns in Ghana (Doctoral dissertation).

[59]. Tobin, J. (1958). Liquidity preference as behavior towards risk. The review of economic studies, 25(2), 65-86.

[60]. Tursoy, T., Gunsel, N., \&Rjoub, H. (2008). Macroeconomic factors, the APT and the Istanbul stock market. International Research Journal of Finance and Economics, 22, 49-57.

[61]. Yauch, C. A., \&Steudel, H. J. (2003). Complementary use of qualitative and quantitative cultural assessment methods. Organizational Research Methods, 6(4), 465481.

\section{Cite this article as :}

Cai Li, Rosemond Atampokah, Helena Akolpoka, Priscilla Avonie, Baku R. Kwame, "The Impact of Macroeconomic Variables on Mutual Funds Performance in Ghana", International Journal of Scientific Research in Science, Engineering and Technology (IJSRSET), Online ISSN : 2394-4099, Print ISSN : 2395-1990, Volume 8 Issue 2, pp. 34-53, March-April 2021. Available at doi : https://doi.org/10.32628/IJSRSET218213

Journal URL : https://ijsrset.com/IJSRSET218213 